\title{
Mediastinal Germ Cell Tumor T3 TNM Finding
}

National Cancer Institute

\section{Source}

National Cancer Institute. Mediastinal Germ Cell Tumor T3 TNM Finding. NCI Thesaurus. Code C146839.

Mediastinal germ cell tumor invading into neighboring structures, such as pericardium, mediastinal pleura, thoracic wall, great vessels and lung. (WHO Classification of Tumors of the Lung, Pleura, Thymus and Heart, 2015) 